\title{
GENRE ANALYSIS AND TASK-BASED COURSE DESIGN FOR ISIXHOSA SECOND LANGUAGE TEACHING IN LOCAL GOVERNMENT CONTEXTS
}

\author{
Mariana Visser \& Edith Venter \\ University of Stellenbosch
}

The successful implementation of a multilingual language policy in the public and private sectors in South Africa depends on vibrant research. This article explores the design and nature of the isiXhosa communication tasks for specific purposes second language teaching in local government context, within a framework of genre-based and task-based approaches to language teaching. These two approaches also form the theoretical basis of the analysis of the rhetorical move structure and the task types of selected communication tasks.

\section{INTRODUCTION}

In 1994 nine African languages were among the eleven official languages listed in the Constitution. If the ideal of widespread multilingualism among all communities in South Africa.is to be achieved, research in the field of second language teaching and learning of the African languages to first language speakers of especially English and Afrikaans is vital. (The term second language as used in this paper refers to any other language a person learns and acquires in addition to his or her first language (i.e. mother tongue)). Implementation of multilingual language policy in South Africa requires, on the one hand, teaching the African languages as second languages during school education to learners who have English or Afrikaans as home languages and, on the other hand, the teaching of African languages for specific purposes in vocational contexts to adults. Research on the latter kind has received very little attention in the South African context. Although there has been some work, for instance by van Huyssteen and Neethling (2001), the work done on isiXhosa for specific purposes constitute mainly unpublished phrase books on the topic of medical examinations, that is, commonly used sentences and phrases used between medical personnel and patients, rather than theoretically-informed course materials. However, it is true to say that extensive work specific purpose course design and materials for isiXhosa, and the African languages, more generally is urgently needed. The research on specific purpose course design for isiXhosa second language teaching in local government which forms the main concern of this article, aims to show the value of theoretically-based work as a means of accomplishing the goal of multilingualism in vocational environments. Effective second language teaching of the African languages for specific purposes to adult learners is dependent on the design of theoretically-informed courses and materials that reflect the kind of design features which would facilitate optimal language acquisition in terms of Valdman's (1989:21) pedagogical norms generally accepted for successful communicative language teaching. 
The concept of pedagogical norm developed by Valdman (1989) refers to a combination of language systems and norms selected by linguists and language teachers to serve as the immediate language target, or targets, that learners need to acquire during the process of teaching and learning. Thus, pedagogical norms represent a mid-point, or series of midpoints, for learners as they progress toward acquiring target language norms. These pedagogical norms have been applied, among others, to teaching grammar, vocabulary, sociolinguistic properties and notions of communicative competence (Odlin, 1994; Bardovi-Harlig \& Gass, 2002; McDonough \& Shaw, 2003). Valdman (1989:21) applies four principles that guide the elaboration of pedagogical norms:

(i) They should reflect the actual speech of target language speakers in authentic communicative situations.

(ii) They should conform to native speakers' idealised view of their speech use.

(iii) They should conform to the expectations of both native speakers and foreign learners concerning the type of behaviour appropriate for foreign learners.

(iv) They should take into account processing and learning factors.

In this article a genre-based approach to language teaching, which invokes the rhetorical organisation of spoken and written text for the purpose of course design (Bhatia, 1993; Henry \& Roseberry, 1998; Garcia-Mayo, 2000), and the task-based approach, which concerns the interaction types involved in communicative tasks (Kumaravadivelu, 1993; Loschky \& BleyVroman, 1993; Long, 2000) form the theoretical framework of this article. These two approaches can be viewed as complementary to each other in that a genre-based approach is essentially concerned with the rhetorical move structure that can be identified in a text for achieving its communicative and social purpose, whereas task-based approaches are concerned with the communicative task types that give rise to optimal language processing and interlanguage development in the process of language acquisition (Pica \& Doughty; 1985; Allwright \& Bailey, 1991: Sharwood Smith, 1993; Van Patten, 1996; Pieneman, 1998, 2000). The notion of interlanguage refers to a second language system reflecting stages of development in the process of acquiring the linguistic system of the target language (BardoviHarlig \& Gass, 2002:3) which second language learners typically pass through as they learn a second language. Viewed from the perspective of the standard grammar of the target language, these stages are generally characterised by ungrammatical linguistic features. The broad stages of interlanguage development in terms of universals, and for specific languages are still the subject wide-ranging research. It is, however, evident that these stages need to be taken into account in the design of course materials and methodology.

This article has three main sections. The first section reviews the theoretical properties of the task-based approach to language teaching and the theoretical assumptions which underlie genre-theoretical approaches. The second section presents an account of the design features of selected communication tasks for specific purpose second language teaching in local Government contexts. The third section presents an analysis of the rhetorical move structure of the communication task as demonstrated in an authentic ${ }^{1}$ dialogue in isiXhosa. 


\section{TASKS IN LANGUAGE LEARNING}

\section{The Concept of Task and Task Requirements}

The concept of task refers to outcome-based activities, in other words, activities for the sake of a given goal. A communication task is an interactional activity with a communication goal. In order to complete the task, learners are expected to request help when they do not understand; they communicate their needs and, at the same time, offer assistance or clarify their own messages. A communication task creates circumstances that allow learners to apply their production and comprehension processes (Kumaravadivelu, 1993; Loschky and Bley-Vroman, 1993; Murphy, 1993; Samuda \& Rounds, 1993; Skehan, 1996 and Long, 2000).

The consensus of opinion is that a task should be designed in such a way that it contributes to the accomplishment of specific language learning objectives and promotes successful language acquisition (Rutherford, 1988; Gass, 1995; Cook, 1996; Jordens, 1996; Seidlhofer \& Widdowson, 1998; Williams \& Evans, 1998; Carroll, 1999 and Brown, 2000). Principles for language learning, such as Long's (1985) Interactional Theory, support the notion that learners should be exposed to comprehensible input and negotiate meaning (see also LarsenFreeman \& Long, 1991; Coyle 2000).

According to (Pica, Kanagy \& Falodun, 1993), the interactant relationship, the interaction requirements, the goal orientation and the outcome options determine the nature of a task and the learners' behaviour. The interactants can all have access to different information needed to complete the task, or only one interactant may hold the information and supply it if the others request it. An interactant can therefore either supply or request information, or both. The communication goal can be similar or convergent, or otherwise divergent for the different interactants. There can be only one acceptable outcome or more than one acceptable possibility.

Pica et al. (1993) contend that a communication task, which would best succeed in eliciting the required learner-behaviour, should meet certain conditions. First of all, every interactant has to have access to different information. Secondly, the interactants have to manipulate and exchange the information in order to complete the task. Thirdly, all the interactants have to request and supply information as to facilitate comprehension and production processes. Finally, negotiation of meaning is best promoted if the interactants have convergent goals and when there is only one possible outcome. These conditions ensure optimum opportunities for learners to produce interpret and comprehend language, to give and receive feedback on production and adjust their interlanguage.

Pica et al. (1993) usefully distinguish the following task types:

\section{(a) The Jigsaw task}

The Jigsaw task is a collaborative, listening activity where learners have to choose and share information so as to complete the task. Both participants hold information which is needed and interaction is therefore imperative. This type of task fulfils all the requirements for a good communication task. 


\section{(b) The Information gap task}

The Information gap task is similar to jigsaw tasks, except that only one of the interactants has access to information that is needed for completion of the task. This means that the other interactant has less opportunity to receive feedback and to modify his or her interlanguage. If the roles are alternated, then this task will fulfil the same requirements as the jigsaw task.

\section{(c) The Problem-solving task}

The Problem-solving task has only a single outcome or solution, and all activity is aimed at finding this outcome. Both interactants have access to the same information that is needed for the task, which means that interaction is not necessary. Interactants could still ask for help or assist each other where there is ambiguity and modify their production as to be more intelligible.

\section{(d) The Decision-making task}

There is a choice of solutions or outcomes in the Decision-making task, but interactants have to work together to decide on one. As with problem-solving, it is not essential that the interactants exchange information, as they already share access to the same information. Interaction is necessary for reaching an agreement about the best outcome, but interactants do not have to participate to an equal degree in the task through either producing language or comprehending production. If there were to be only one acceptable, predetermined outcome, then the task would be essentially a problem-solving task.

\section{(e) The Opinion exchange task}

The Opinion exchange task can be built into any discussion. There is considerable flexibility. For instance, interactants are not forced to participate and they do not necessarily share the same communication goal. There is not a single, acceptable outcome which would compel mutual understanding. Were it to be agreed that interactants would have to decide on one outcome, then there would be more opportunity for production, comprehension and interlanguage modification. With only one acceptable outcome, the features of the task be similar to that of a decision-making task.

\section{TASKS THAT FOCUS ON FORM}

An increasing concern in language teaching is how to focus on form without sacrificing genuine communication. According to Doughty and Varela (1998), a communicative focus on form (FonF) emphasises fluency, rather than linguistic correctness and views language as the means of communication, not the object of communication. Long and Robinson (1998) suggest that this kind of focus on form could be accomplished in a variety of ways - from explicit metalinguistic rule explanations to implicit visual input enhancement. They argue that implicit and inductive FonF is better suited for complex language and marked structures; whereas explicit deductive FonF is appropriate for simple language, where salient features of form directly influence the meaning. 
Of particular interest to those concerned with optimising the advantages of classroom-based learning, studies have shown that Second language (L2) learners who receive instruction have an advantage over naturalistic L2 learners and that focus on form promotes (Second language acquisition (SLA), while it prevents fossilisation. Task-based grammar instruction develops L2 learners' grammar through hypothesis testing and inferencing. Consciousness raising activities at sentence level show how the lexico- and morphosyntax influence the meaning (Fotos, 1993; Larsen-Freeman, 1995; Ellis, 2001; Leow, 2001; Bandar, 2004). According to Loschky and Bley-Vroman (1993) closed, information gap tasks are best for focus on form. They differentiate between closed tasks, which are determined or discrete, as opposed to open tasks that are undetermined. Closed tasks facilitate more negotiation of meaning, interlanguage modifications, as well as greater comprehension and focus on form, because the information needed for the successful completion of the task is very specific.

\section{REFERENTIAL COMMUNICATION TASKS}

\section{Developing Tasks for Information Exchange}

Yule (1997) defines referential communication tasks as transactional tasks that are characterized by extended, structured discourse and are typically found in instructional environments where the context can be determined. Yule (1997) explains that in this sense target does not refer to the target language, but to a target repertoire. The emphasis is on the ability to use the L2 in communicative exchanges. L2 messages are formed and expressed within communicative events. Yule points out that the discourse is purposeful and controlled in that there is a defined topic, as well as prescribed materials, a procedure and a point of completion that is reached when a set objective is achieved. Transactional communication is concerned with concepts like sender and receiver, and message encoding and decoding. Yule distinguishes between one-way information flow where the information is essentially transferred and two-way information flow where information is exchanged. He describes tasks as open, when the goal is undefined and information exchange is optional. Closed tasks are designed as to require information exchange and a convergent effect within the task performance to reach a common goal.

According to Yule (1997) referential communication tasks do not have any predetermined set of linguistic forms that have to be used. The function of the task is purely to elicit speakers' discourse. Yule notes that different task types elicit different kinds of discourse, such as instructions or descriptions. He explains that in principle a referential communication task has to provide the speaker with some pre-selected information to convey, the listener with a reason to obtain the information in order to complete a task, and the awareness that the information gap exists. Yule maintains that the roles of speaker and listener, or sender and receiver, demand the skills of recognising the interlocutor's perspective, to make assumptions about their perspectives based on which the message is encoded and decoded, and to measure these assumptions to any feedback received. Yule therefore maintains that each participant has to assume a social role in referential communication. The social values that these roles represent, such as status, familiarity, expert or gender, have to be recognized in order for the participant to communicate effectively. In order to negotiate meaning and communication outcomes learners have to use communication strategies. These strategies for negotiation of meaning include clarification or repetition requests, and confirmation or comprehension checks. 


\section{INSTRUCTIONAL TASKS}

There are different definitions for the concept of "instructional task". This variance indicates underlying differences in approach to methodology and content of L2 teaching. Kumaravadivelu (1993) discussed different views of this concept. He refers to the view of tasks as skills that learners practise in the classroom for non-instructional objectives (in other words, for social communication) outside the classroom. Kumaravadivelu views a task as one of a series of ordered problem-solving activities. He notes that Nunan views the instructional task as a communication task, which involves the language learner in comprehension, manipulation, production and interaction activities, whilst they focus on meaning rather than form.

According to Kumaravadivelu (1993) a task-based perspective defines the instructional task as a communication task that is performed within a meaning-focused and interactional, methodological context. Task-based teaching represents a shift back to method-orientated teaching, which recognises the need for not only planning objectives and content but for specific classroom implementation. Nunan (1993) focuses on the integrated processes of learning and teaching: the surrounding classroom context and learners' participation, via their own interpretation of the content and objectives.

Long and Crookes (1993) identify a six phase design programme for task-based teaching: firstly a learner's needs identification is required - this is conducted according to the realworld target tasks that learners are preparing to undertake. Secondly, the specific target tasks are identified and classified according to more general task types. Thirdly, pedagogic tasks are derived from the task types, which are graded and sequenced to form a task-based syllabus. Fourthly, pedagogic tasks are graded according to the number of steps and possible outcomes, the apparent cues, and the context in terms of time and place. Fifthly, task type and classroom routine also affect task grading. Pedagogic tasks become increasingly complex, along with the learners' developing abilities, approximating target tasks in communicative success, semantic accuracy, pragmatic appropriacy, and grammatical correctness. Finally, evaluation is important for summation of the learning that has taken place, as well as to identify problem areas.

\section{SPECIFIC PURPOSE COURSE DESIGN}

According to Grenfell (2000), theories about what it means to know a language determine what has to be learned and how to teach it. Cognitive theorists would prescribe meticulous application of the mind to learning vocabulary, analyzing grammar and drilling example exercises in order to know the formal properties of a language. Communicative theorists focus on the need and ability to understand and be understood, but in practice communicative language teaching (CLT) facilitates imitation of real world communication, not real communication. Grenfell discusses the view of the nature and process of language as having two facets: communicative action and strategic action. Communicative action aims at effective transmission of knowledge, and strategic action is goal-orientated. Communicative and strategic actions function together under specific controlled conditions that cannot be generalised. 
Grenfell (2000) considers the Vygotskian perspective, which is based on a cognitive view of language learning and considers declarative and procedural knowledge as important forms of information. This perspective builds upon the theory of information processing, which declares that much of what we know (declarative knowledge) and what we know how to do (procedural knowledge) we do automatically or unattended. It is only when we are confronted with new input or a problem that we recall the procedure step-by-step. Grenfell states that when a second language is learned it is necessary to gain control over the necessary L2 vocabulary and the appropriate L2 linguistic structures (declarative knowledge), as well as to gain control over ourselves and objects and people in the L2 world (procedural knowledge).

Grenfell proposes a six-step plan for teaching learning strategies: firstly the learners are introduced to a strategy through consciousness-raising. Secondly, the strategy is modelled by example. Step three requires the learners to practice the strategy performing a classroom task. Fourthly, the task is individualised in opportunities for action-planning or goal-setting and by monitoring their meta-cognitive awareness. Step five entails meaning-focussed practice that brings about automaticity, and the final step entails evaluating the strategy and recommencing the cycle.

\section{TASK DESIGN FEATURES FOR ISIXHOSA IN LOCAL GOVERNMENT}

In this section a framework for task-based course design is explored for isiXhosa second language learning for specific purposes for local government workers. A series of target tasks was identified for task-based vocational language teaching. The vocational context for isiXhosa second language learning is the municipality. A study conducted at the Overstrand Municipality in the Western Cape is described as basis for identifying the scope and range of the task-design.

The article demonstrates a selection of the target tasks that were analysed according to the task typology, as described by Pica et al. (1993), and Yule's (1997) principles of referential communication. The generic structures and underlying lexical phrases, which are considered to be task essential for obligatory genre moves were analysed. The purpose of this analysis is to provide a basis for developing learning tasks, which focus on form, and to possibly illustrate tentative task complexity.

\section{THE SCOPE AND RANGE OF THE TASK-DESIGN}

\section{The Learner Population}

The learners concerned were all employed by the municipality. Municipalities consist of different departments that deliver public services. These local departments represent the provincial and national government departments at a local level and include the departments of finance, health, protection, engineering, law enforcement, housing and human resources. The traffic department, fire brigade, clinics and town's libraries, also form part of the municipality. Within each department there are different ranks, which ranges from a head of department to the worker at the lowest level. There are also administrative personnel who do 
not deliver a public service, but work exclusively with personnel issues, like salaries and training, and the general running of the municipality.

The study at Overstrand Municipality in the Western Cape showed that the greatest need for isiXhosa second language learning is amongst the municipal workers who work either with the general public or who are managers of divisions with Xhosa-speaking workers with a low level of literacy, or who have no formal education. At the moment the Xhosa speaking population in the Western Cape in general, and specifically in the Overstrand Municipal area, is growing. According to a report from the Interim Assistant Municipal Manager of Communication for Overstrand Municipality, dating back to March 2001, the Xhosaspeaking voters in the area constitute 24 per cent of the total number of voters and are still a young population. A safe assumption is that isiXhosa will increase in importance as a regional language. At the moment the use of interpretation and translation services is a necessary and an essential solution for the growing communication needs in this municipal area.

The Communication Policy and Strategy Framework for the Overstrand Municipality, which was released in February 2001 underlines only one of the communication needs in local governments, namely communication with the local community whom they represent. The Local Government: Municipal Systems Act, 2000 (Act 32 of 2000) places a duty on a municipal council to consult the local community about services delivery. The Overstrand Communication Framework acknowledges the Constitution's objective to recognise communication and participation with local communities and to provide democratic and accountable government.

Local government can facilitate participation by ensuring effective communication. The Overstrand Municipality Communication Strategy concludes that open channels of communication, both internal and external, are the key to meaningful participation. It seems therefore that for reasons of effective service provision and meaningful participation, both in the local government departments and with the public, all non-native municipal workers would benefit from beginners' isiXhosa task-based teaching for specific purposes.

\section{THE VOCATIONAL CONTEXT FOR LANGUAGE LEARNING FOR SPECIFIC PURPOSES}

The underlying assumption of second language teaching for specific purposes prepares the learners for the occupational eventualities (Cook, 2003; Wieden, 1998; Barnard \& Zemach, 2003). However, specifying the scope of the task design for task-based second language teaching is problematic since pedagogic tasks have to equip the learner with the communication skills needed for real world activities. In this specific case, the problem was that local government departments, or municipalities, include a large variety of jobs and specialisations in distinct fields. The domain-specific words vary not only from one department to another, but from internal language to external language. Although some departments, and specific professions within those departments, communicate more with the public than others; the study at Overstrand Municipality has shown that all the departments, and almost all municipal workers, communicate externally to a certain extent. More significantly, the Overstrand Municipality study revealed that internal communication amongst different departments is an everyday occurrence. 
In order to learn domain-specific language, the local government worker needs domainspecific knowledge. Acquiring the knowledge and the language is often in reality one process. In the municipality, as in many vocational settings, many concepts are not represented with a specific term for every language; but a single label is used in to refer to a tool or a process, a person or a place. Using isiXhosa in the vocational settings of local governments would typically import foreign borrowings to form a multi-lingual vocabulary. As predicted by Thorogood (2000), in such a dynamic field as local government, new knowledge would also require concepts being extended or newly created.

What seems essential is that the areas of communication that are shared by all the domains of the local government departments, and the communicative skills that constitute the competence necessary for a municipal worker to communicate with colleagues, junior or senior workers, and the public, as well as the learning strategies necessary to enable them to continue developing their ability, should be covered by the task design.

\section{TARGET TASKS FOR TASK-BASED VOCATIONAL LANGUAGE TEACHING IN LOCAL GOVENMENT}

\section{Identifying Real World Tasks of Municipal Workers}

The aim of the research was to determine target tasks for a task-based beginner isiXhosa course for the specific purposes of local government workers.

Seventy-two municipal workers, representing all the different departments and ranks within the departments, were assigned quasi-randomly by a personnel officer from the Human Resource department of Overstrand Municipality. Each participant was given a questionnaire pertaining to internal and external communication contents. The questionnaire aimed at establishing the content of what was being said and to whom it was being said. Participants had to indicate to what extent interaction with, or about other municipal departments occurred on a regular basis, both internally with other municipal workers, and externally with the general public. Stretches of conversations, as well as expressions that they regularly use at work were recorded. Participants completed the questionnaire in writing or orally, which was recorded on cassette in some cases, along with discussions about their answers.

The questionnaires and recordings were analysed to differentiate common areas and specialised areas of communication contents. It became apparent that there is frequent interaction between all the departments of the Overstrand Municipality. This is especially true of maintenance problems that require the services of the engineering departments, problems with salaries and leave, and issues regarding training and promotion were areas of internal communication that occur in every department and at every level of employment. General language functions, like apologising and sympathising or giving directions; and notions of time and money; and contents of language acts, like completing forms and work orders or writing reports applied in all the different departments. External communication contents related to providing services and included many of the contents identified for internal communication, as well as contents for making excuses, hearing excuses, describing municipality policies and explaining procedures. 
After general contents of communication and essential interactional skills for communicative competence were identified from the questionnaires and interviews for real world tasks, ten target tasks were described. These target tasks represented the real world tasks of specific municipal workers for internal and external communication. In some cases the tasks were very job specific, and in other cases the tasks were relevant to many different jobs in the municipality. In all cases these tasks represent communication contents and skills pertinent for all the departments of Overstrand Municipality. The rationale was that even if the specific task does not represent what a municipal worker will be called upon to do, he or she should be able to relate to the task and therefore be motivated to participate.

\section{TARGET TASKS ANALYSIS}

\section{Task Typology Analysis}

A selection of the target tasks that were selected from real world tasks of municipal workers are now discussed according to considerations relating to task type and the requirements for communication tasks as described by Pica et al. (1993). The interactant relationship, interaction expectations, goal orientation, and outcome options are discussed. The potential of some of the tasks to elicit referential communication is identified, as well as the participants' roles as described by Yule (1997).

Each task is first formulated in the target language, isiXhosa, and is followed by a free English translation. These translations aim to provide a general idiomatic version of the isiXhosa sentences, rather than representing the intricacies of the English equivalents of the isiXhosa contents.The task typology analysis follows the task description, and is aimed at demonstrating the potential of each task to create opportunities to negotiate meaning and task outcomes in order to promote isiXhosa second language acquisition.

\section{a) Task One}

Ilungu lasekuhlaleni litsalela umnxeba umasipala licele ukuthetha nomntu ophethe icandelo, uMnumzana Burger. UMnumzana Burger uzazisa ngokwakhe kwaye anike uncedo. Umntu uthi abuze malunga nokucima kombane kwaye umbane ungawulindela ukuba ungabuya nini. Umnumzana Burger umchazela uhlobo lwengxaki kwaye umxelela umntu ukuba kukho injineli elungisa ingxaki. Umntu aye akhalaze esithi uxakekile uyapheka kwaye akakwazi ukuqhubeka ngaphandle kombane. Umnumzana Burger unika ixesha loqikelelo acinga ukuba ukulungisa kuya kulithatha. Ilungu lasekuhlaleni kwakhona lichaza nesibane sasendleleni esophukileyo endlini yakhe. Umnumzana Burger ubuza malunga neyona ndawo yesibane sasendleleni. Umntu ubuza ukuba isibane esi siyakulungiswa nini. Umnumzana Burger umchazela inqubo kamasipala yesibane sasendleleni kwaye umchazela umntu ukuba iya kuba lithuba. Umntu uye akhalazele malunga nokulibaziseka. Umnumzana Burger uyaxolisa kodwa ecacisa ukuba umntu kufuneka abe nomonde. Bathi bebulisana.

(A member of public phones the municipal electric services and asks to speak to the head of the department, Mr Burger. Mr Burger introduces himself and offers assistance. The person inquires about the nature of the power failure and when the power can be expected to be switched back on. Mr Burger explains the nature of the problem informs the person that there is a technician who is fixing the problem. The person complains that she is busy cooking and cannot continue without electricity. Mr Burger gives an estimated time that the reparation would take. The member of public then reports a broken streetlight at her house. 
Mr Burger inquires about the exact position of the streetlight. The person asks when the light will be fixed. Mr Burger explains the municipality's streetlight programme and informs the person that it could be a while. The person complains about the delay. Mr Burger apologizes but explains that the person has to be patient. They take leave of each other.)

The first part of this task is a typical information gap task (Pica et al., 1993) with the municipal worker having the information and the member of public asking for information about the power failure. The goal orientation is divergent for the member of public expects immediate restoration of the electricity or a satisfactory explanation for a delay; while the municipal worker expects appreciation for the circumstances and patience from the member of public. The only acceptable outcome is the member of public's satisfactory understanding of the problem and its expected duration. The second part of the task is a typical jigsaw task, with both interactants holding information needed to complete the task. The member of public has information about the location of the broken streetlight and the municipal worker has information about the procedure of streetlight maintenance. The goal orientation is convergent in the sense that the municipal worker and the member of public want to be satisfied that the report is properly submitted and would be attended to. When the member of public is giving directions and identifies the position of the broken streetlight, the task could be elaborated with more detailed instructions or even tracing a route, where the information follower has to create specific referents or landmarks in town.

\section{b) Task Two}

Ilungu lasekuhlaleni litsalela umnxeba unobhala kwimibuzo licele inkcazelo malungu nezigqubo zabachithi-holide zikamasipala. Unobhala uchaza izigqubo ezibini ezingaphantsi lolawulo lwabo lwezobulingisa. Umntu uthatha isigqibo sokuba abhukishe impelaveki kwindawo yokuhlala kwisigqubo sabachithi-holide eOnrus. Unobhala ngosizi umxelela umntu ukuba ayikho indawo kwimpelaveki ebuziweyo. Umntu uye agqibe komnye umhla. Unobhala ngelo xesha uye amchazele izindlu, ezilala abantu abane. Umntu ufuna indawo yokuhlala abantu abathandathu. Baxoxa iindleko eziqukayo kwaye baqinisekise ukubhukisha kwendawo. Umntu ubuza malunga nommandla kwaye unobhala amchazele ngendawo ezintathu zabatyeleli ezinomtsalane. Umntu uyabuza indlela eya kwisigqubo sokuchitha iholide saseOnrus kwaye unobhala umnika iinkcazelo. Unobhala ufuna ukumthumelela ifomu yesicelo kwaye umntu uye amnike inombolo yakhe yefeksi. Bayabulisana.

(A member of public phones a clerk at inquiries and requests information regarding the municipal holiday resorts. The clerk describes the two resorts under their jurisdiction. The person decides to book accommodation at Onrus Holiday Resort for a weekend. The clerk regrettably informs the person that there is no accommodation available on the weekend in question. The person decides on another date. The clerk then describes the cottages, which sleep four people. The person seeks accommodation for six people. They discuss the costs involved and confirm the booking. The person inquires about sights in the area and the clerk describes three tourist attractions. The person asks for the way to Onrus Holiday Resort and the clerk gives her directions. The clerk wants to send an application form and the person gives her fax number. They take leave of each other.)

This is a jigsaw task (Pica et al., 1993), with both interactants having access to information needed for successful completion of the task. Interaction is required to share the information in order to make decisions. The member of public has information about the preference and needs of the group that the booking is made for. She also has a contact number (fax number). 
The municipal clerk has access to information about the facilities available, as well as to instructions on how to get there. Both interactants have to manipulate the information they hold by making requests, asking for clarifications and explanations, and supplying information in order to achieve a convergent goal: to hire a cottage for six people for a weekend that ends on the Sunday afternoon. There could be more than one possible outcome, but the interactants have to agree on the best option. The part of the task where the municipal worker is the instructor and the member of public the instructee for directions to the municipal holiday resort could be devised as to elicit more explicit referential communication.

\section{c) Task Three}

Ilungu lasekuhlaleni lingena kwicandelo lezithuthi kwaye lifuna ukwenza isigqibo sokudibana ukuba libhale iphepha-mvume lakhe lokufunda ukuqhuba. Umnumzana Gerber umbuza ukuba unaso isazisi kunye nemali kuye, uye aqinisekise ukuba unazo. Umnumzana Gerber umnika ifomu ukuba ayizalise kwaye enze uvavanyo lwamehlo kunye nomntu. Bathi bebhukisha isigqibo sokudibana sokubhala uviwo lwephepha-mvume lokuqhuba kwaye uMnumzana Gerber amchazele umntu ukuba yintoni ekufuneka aze nayo kwisigqibo sokudibana. Umnumzana Gerger ubhala iinkcukacha zesigqibo sokudibana kwiresiti yomntu, amnike iresiti kwaye uye afune imali.

(A member of public enters the traffic department and wants to make an appointment to write her learner-driver's license. Mr Gerber asks her if she has her identification document (ID) and money with her, and she confirms that she has. Mr Gerber gives her a form to complete and conducts an eye-test on the person. They book an appointment for the writing of the learner-license test and $\mathrm{Mr}$ Gerber explains to the person what she will need to bring to the appointment. Mr Gerber writes the details of the appointment on the person's receipt, he then gives her the receipt and asks for the money.)

This is an information gap task (Pica et al., 1993) where one participant requests information and the other supplies the information. The goal orientation is convergent: to make an appointment for the client to write a learner-license examination. In the first part of the task the municipal worker requires information about the kind of license and personal details from the member of public. In the second part of the task the municipal worker is requesting information from the client about the position of the check block. The municipal worker has access to the correct answers and has to evaluate the client's responses. In the last part of the task part of the task the municipal worker has access to different outcome possibilities: possible dates and times for the appointment. The municipal worker provides information and requests information from the client, but the client is only required to provide information.

\section{d) Task Four}

Ilungu lasekuhlaleni litsalela umnxeba kwamasipala libuza malunga netyala elingalindelekanga lamanzi eliphakamileyo alifumeneyo. Umsebenzi wakwamasipala, umabhalana kwimibuzo yamatyala, uyabuza ukuba ingaba umxhasi uyalukhangela ufundo lwamanzi akhe rhoqo, kodwa umxhasi uphendula ityala lakhe libhatalwa ngokwenyanga ngokuxhuzulwa. Umabhalana ubuza emva kwesehlo esingaqhelekanga endlwini yomxhasi enokuthi ikhokelele ekunyukeni kokusebenzisa amanzi. Umxhasi uyaphika ukuba kukho into engaqhelekanga ethe yenzeka. Umabhalana umgqithisela umxhasi kwisilinganisi-manzi 
kwaye amcacisele ukuba ukuvuza makakujonge njani. Umxhasi uyavuma ukukhangela kwaye aphinde amtsalele umnxeba emva koko. Umbuza umabhalana igama lakhe ukwenza isiqiniseko. Umxhasi umtsalela kwakhona umabhalana emxelela malunga nokuvuza okukwisixokelelwano sakhe samanzi. Umabhalana umlumkisa umxhasi ukuba ngumthwalo wakhe kwaye umcebisa ukuba afune uncedo lomtywini ngokukhawuleza. Umxhasi ukhalaza malunga netyala eliphakamileyo ngokuba akakwazi ukulibhatala. Umabhalana umcebisa ukuba abhatale kwaye abhatale oko aqhele ukubhatala kwaye abhale ileta echaza ingxaki yakhe.

(A member of public phones the municipality to inquire about an exceptionally high water account that she has received. The municipal worker, a clerk at debtor inquiries, asks if the client checks her water reading regularly, but the client replies that her account is paid monthly by debit order. The clerk tries to establish whether there are any unusual circumstances at the client's house that could lead to an increase in water consumption. The client denies that anything out of the ordinary has happened. The clerk suggests that the client look at her water meter and explains how to look for a leakage. The client agrees to investigate and to phone afterwards. She asks the clerk's name for reference. The client phones back and informs the clerk of a leakage in her water system. The clerk warns the client that the problem is her responsibility and advises her to acquire the help of a plumber immediately. The client complains about the high account that she is unable to pay. The clerk recommends that she pay what she usually does and that she write a letter to explain her problem.)

This is a jigsaw task (Pica et al., 1993) where both participants request and supply information. The clerk holds information about the possible reasons for the high water account, about the procedure to follow to check for a water leakage, and about solutions for the problems with the plumbing and the high account that has to be paid. The client holds information about the circumstances in her household and she has access to the water meter. The goal orientation is convergent and both participants want to settle the water account. The task outcomes include finding the reason for the high water consumption and to fix the problem. Interaction is essential and negotiation of meaning is complicated by the medium of communication. Directions and descriptions are done on the phone and non-verbal forms of communication, like facial expressions or physical illustrations, are excluded.

\section{e) Task Five}

Ilungu lasekuhlaleni licela indlu kwisebe lezindlu kunye nenkqubela yomzi. Umongameli wezindlu, uMnumzana Williams, uyamncedisa. Umcacisela umxhasi imeko ekhoyo kwaye akukho zindlu zikhoyo, kodwa ifomu yoluhlu lokulinda kufuneka ayizalise. Umongameli wezindlu uye amcacisele inkqubo yodidi kunye nendlela abathi bakhethe ngayo abaviwa bezindlu. Umcebisa umxhasi ukuba azalise ifomu uye amlumkise ukuba abanye bangangena kuluhlu lokulinda phambi kwakhe ukuba uyalinda. Umongameli wezindlu umcacisela ukuba ifomu ikhona ngeelwimi ezintathu ezivumelekileyo zephondo kwaye uye amnqinisekise umxhasi ukuba ukhona umntu okhoyo oza kumncedisa ekuzaliseni ifomu nangaluphi na ulwimi. Umxhasi umchazela indlela ahlala ngayo ngoku kwaye udinga indawo entsha yokuhlala. Umongameli wezindlu umcacisela ngelungelo lokukhetha elikhoyo kwaye angalifumana njani ilungelo lokumisa isakhiwo sexheshana.

(A member of public requests housing at the housing a community development department. A housing officer, Mr Williams, assists him. He explains to the client the current situation and that there is no housing available, but that a waiting list form has to be completed. The 
housing officer describes the process of ranking and selection of candidates for housing. He advises the client to complete the form right away and warns him that others could get in on the list before him if he waits. The housing officer explains that the form is available in the three official languages of the province and assures the client that there is someone available to help him complete the form in any of the languages. The client explains his current living arrangement and that he is desperate for new accommodation. The housing officer explains the options available and how to go about acquiring permission for erecting a temporary structure.)

This is an information gap task (Pica et al., 1993). The member of public requests information, while the housing officer supplies information. The goal orientation in convergent and both the participants aim at identifying a plan of action for the client to obtain housing. The task outcomes are the client's understanding of the process of obtaining housing, the intermediate options and the housing waiting list form. As it is the task does not require any immediate decision-making or actions, but these are possible outcomes that could be built into the task. Negotiation of meaning is important because of the sensitive nature of the task topic. The client approaches the communication event with expectations of immediate results and has to understand the long-term nature of the national housing project.

The task typology presented above demonstrates how second language acquisition of isiXhosa in local government contexts can be enhanced through consideration of how the architecture of tasks can facilitate the acquisition process and, in particular, how the task typology relates to the theoretical assumptions that inform both content and methodology in terms of the notions of instructional tasks as meaning-focused and interactional tasks (Kumaravadivelu, 1993). The tasks in isiXhosa also illustrate Yule's (1997) notion of referential communication tasks as transactional tasks that are characteristically defined within instructional environments where learners have to use communication strategies to negotiate meaning. The specific purpose course design of isiXhosa for local government had to take account of these properties.

The analysis of the rhetorical moves of communication tasks given above is an important step of task-analysis and design for the purpose of giving conscious attention to the teaching of the discourse or generic structure and the linguistic structures that realise the communicative purpose, to second language learners in the instructional process. As noted on page 37, a genre may be defined as a spoken or written text that serves a particular social or communicative purpose in society and is composed of a series of segments called cognitive or rhetorical moves (Bhatia 1993; Henry and Roseberry 1998; Garcia-Mayo, 2000). The move-structure analysis below demonstrates for the isiXhosa communication tasks the respective obligatory and optional moves. Obligatory moves are necessary to achieve the communicative purpose of the genre, whereas optional moves add to the effectiveness of the communication but do not alter the purpose of the genre.

\section{MOVE-STRUCTURE ANALYSIS}

In this section the move-structure of Target Task One is analysed according to the obligatory and optional moves for the given genre. The numbers used in the analysis refer to the lists of obligatory and optional moves for the communicative purpose which are listed below the dialogue. A genre-type represents one or more communicative purpose and employs general 
conversational moves to realise those purposes. The dialogues were recorded for reference with the numbers of the moves as they are analysed for task one below. It should be noted that this is not a complete list of all the conversational moves that occur in the recorded dialogues, but that only those moves which are required for the successful completion of the tasks, or which contribute to the effectiveness of the communication, are represented.

\section{Task One}

Dialogue

Ilungu lasehlaleni (L)

UMnumzana Burger (B)

B: $\quad$ Inkonzo zombane eOverstrand

(Overstrand Electrical Services)

L: $\quad$ (4)Molo, (1) [ndingathetha noMnumzana Burger?]

(Good morning, may I speak to Mr Burger?)

B: $\quad$ (4)Molo Nkosikazi, (2) [nguMnumzana Burger othethayo.] (5) [Ndingakunceda ngantoni?]

(Morning Madam, this is Mr Burger speaking. How can I help you?)

L: $\quad$ (3) [Ndingathanda ukwazi ukuba yintoni ingxaki nombane.] (6) [Kutheni umbane ucimile?]

(I would like to know what the problem is with the electricity. Why is the power off?)

B: $\quad$ Nenekazi, (7) [sinengxaki neengcingo zombane] ezilele phantsi emhlabeni (10) [ngenxa yemimoya emikhulu] ebekhe sanayo. (11) [Sixakekile sijonga yonaenye yenjineli seyilapho ukuyokujonga ukuba eyona ngxaki yintoni.] (13) [Sakuyilungisa ngokukhawuleza nangokungxama.]

(Lady we have a problem with electrical lines which are lying on the ground because of the strong winds we have had. We are busy to see to it - one of our technicians is already there to see what the exact problem is. We will repair it as quickly as we possibly can.)

L (12) [Ndixakekile ndiyapheka.] (8) [Uya kubuya nini umbane?]

(I am busy cooking. When will the power come back on?)

B: $\quad$ Nkosikazi kunzima ukutsho: (9) [ungathatha isiqingatha seyure okanye iyure.] Sisebenza ukutsho, malunga neeyure ezimbini, kodwa kunzima ukubuyisela umbane kwangoku. Kukho umsebenzi okufuneka wenziwe kwaye kufuneka ugqitywe kuqala phambi kokuba sibuyisele umbane.

(Madam that is difficult to say: it could take a half an hour or an hour. We work on say, about two hours, but it is impossible to put the electricity back on right away. There is work to be done and it has to be finished first before we can restore the power.)

L: $\quad$ (14) [Ndiyaqonda Mnumzana,] (15) [enkosi.] (16) [Ndifuna ukwazisa malunga nesibane sasendleleni ngaphandle kwendlu yam, esingasebenziyo] (20) [kwezintsuku zimbini zigqithileyo.] (22) [Ndingakubuza ukuba uza kuza nini ukuza kusilungisa?]

(I understand Sir, thank you. I also want to inform you about a streetlight outside my house, which has not been working for the last two days. May I ask when are you coming to repair it?) 
B: $\quad$ Nkosikazi, (17) [unganceda undinike idilesi ethe ngqo kunye nendawo yesibane.] (Madam, if you can please just give me the exact address and position of the streetlight.)

L: $\quad$ (18) [Isibane sisesitalatweni sesixhenxe kwisangqa sezithuthi.] (21) [Ndihlala kwanombolo weshumi elinesithandathu kwisitalato wesixhenxe kwaye esi sibane sophukileyo siphambi kwendlu yam.]

(The streetlight is in Seventh Street at the traffic circle. I live in number sixteen Seventh Street and the broken streetlight is in front of my house.)

B: $\quad$ Nkosikazi, (19) [ewe, singeza sizokusijonga], kodwa (23) [sinenkqubo yesibane zasendleleni ethe yayohlula idolophu yayimimandla emine. Into eza kwenzeka ngoku siza kwenza i-odolo yomsebenzi yokulungisa eso sibane sasendleleni. Emva koko iya kuthi ifakelwe ngexesha elilodwa elabelwe lo mmandla.] Ngendlela yokuba (24) [ingakule veki izayo.] Ndiza kukhe ndijonge ukuba ingeniso yenkqubo, kodwa ndicinga ukuba uhlala eVoëlklip uwela kwiveki yesine enyangeni, kwaye kuya (25) [kufuneka ube nomonde kuba ingathatha ixesha.] (Madam, yes we can come and have a look at it, but we have a streetlight programme according to which the town has been divided into four areas. What will happen now is that we will make out a work order for repairing that streetlight. Then it will have to be fitted within the specific time allocated for that area. So, that can be next week. I will just have a look at how the programme proceeds, but I think that if you stay in Voëlklip you fall into the fourth week of the month, and you will just have to be patient because it could take a while.)

L: $\quad$ (26) [Kodwa Mnumzana Burger, kwesi sithuba kumnyama tshu ngaphandle kwendlu yam, kwaye ndihlala ndedwa!]

(But Mr Burger in the mean time it is pitch dark outside my house, and I live alone!)

B: $\quad$ (27) [Ndiyaxolisa kakhulu ngaloo nto Nkosikazi,] kodwa njengokuba bendikuchazele malunga nenkqubo akukho nto endinokuyenza malunga nayo. (I am very sorry about that Madam, but as I have explained we work according to a programme and there is nothing that I can do about it.)

L: $\quad$ (28) [Kulungile Mnumzana Burger,] (29) [uhlale kakuhle.]

(Alright Mr Burger, good bye.)

B: $\quad$ (29) [Ube nemini emnandi nawe Nkosikazi.]

(Good day to you Madam.)

Communication Purpose One: Establishing a telephone conversation between the head of the department $(B)$ and a member of public $(L)$.

\section{Obligatory moves}

(1) asking for person B

(2) identification of speaker(s)

(3) identifying the purpose of the call

\section{Optional moves}

(4) greeting

(5) offering assistance 


\section{Communication Purpose Two: Inquiry about a Problem}

\section{Obligatory moves}

(6) requesting reason for problem

(7) stating problem

(8) inquiring about duration of problem

(9) stating time approximation

\section{Optional moves}

(10) describing nature of the problem or describing the reason for the problem

(11) explaining procedure for rectifying problem

(12) complaining about the consequences of the problem to establish urgency

(13) making excuses for delay or reassuring that repair is in progress

(14) indicating comprehension

(15) stating appreciation

\section{Communication Purpose Three: Reporting a Problem}

\section{Obligatory moves}

(16) reporting problem

(17) asking the exact location of the problem

(18) identifying location of the problem

(19) agreeing to attend to the problem

\section{Optional moves}

(20) describing exact nature of problem

(21) instructions for how to get there

(22) requesting exact time of repair

(23) explaining procedure for repair

(24) stating approximated time for repair

(25) requesting patience

(26) complaining about inconvenience caused and establishing urgency of problem

(27) sympathizing or apologizing for inconvenience caused

(28) acceptance of apology

(29) greeting

\section{CONCLUSION}

There is an urgent need to design theoretically-based courses in African languages for specific purposes. This article represents an attempt to demonstrate how genre-based and task-based approaches can be used to underpin a specific purpose course design for isiXhosa second language teaching. Further research is field is necessary to address aspects such as the interaction between theoretical issues in second language processing and acquisition, on the one hand, and the realisation of pedagogical norms in the sense of Valdman (1989) in the 
design of courses and materials. Another important area of future research concerns the question of how interlanguage development of second language learners of African languages can be facilitated in an optimal way through analysis of the linguistic structures essential to realise rhetorical moves in communication tasks. The establishment of a dynamic and extensive research field for specific purpose course design for African languages is essential in accomplishing the successful implementation of multilingualism in both the public sector and private sector in South Africa.

\section{END NOTE}

${ }^{\mathbf{1}} \mathrm{An}$ isiXhosa mother-tongue informant was used in constructing the dialogue.

\section{REFERENCES}

ALLWRIGHT, D \& K BAILEY. 1991. Focus on the language classroom: An introduction to classroom research for language teachers. Cambridge: Cambridge University Press.

BANDAR, A-H. 2004. Attention and awareness: Evidence from cognitive and second language acquisition research. Working Papers in TESOL \& Applied Linguistics, 4(1): $1-21$.

BARDOVI-HARLIG, K \& SM GASS. 2002. Introduction. In Gass, SM, K Bardovi-Harlig, SS Magnan, and J Walz (Eds), Pedagogical norms for second and foreign language learning and teaching: Studies in honour of Albert Valdman. Amsterdam: John Benjamins Publishing Company.1-14.

BARNARD, R \& D ZEMACH. 2003. Materials for Specific Purposes. In Tomlinson, B (Ed), Developing materials for language Teaching. London: Continuum. 306-323.

BHATIA, VK. 1993. Analysing genre: Language use in professional settings. London: Longman.

BROWN, K. 2000. Conclusion: Creative thinking about a new modern languages pedagogy. In Green, $\mathrm{S}(\mathrm{Ed})$, New perspectives on teaching and learning modern languages. Clevedon: Multilingual Matters Ltd. 138-157.

CARROLL, SE. 1999. Putting input in its proper place. Second Language Research, 15(4): 337-388.

COOK, VJ. 1996. Universal grammar in second language acquisition. In Jordens, P \& J Lalleman (Eds), Investigating second language acquisition. Berlin: Mouton de Gruyter.167-186.

COOK, VJ. 2003. Materials for adult beginners from an L2 user perspective. In Tomlinson, B (Ed.), Developing materials for language teaching. London: Continuum.275-290.

COYLE, D. 2000. Meeting the challenge: Developing the 3Cs curriculum. In Green, S (Ed), New perspectives on teaching and learning modern languages. Clevedon: Multilingual Matters Ltd. 
DOUGHTY, C \& E VARELA. 1998. Communicative focus on form. In Doughty, C. \& J Williams (Eds), Focus on form in classroom second language acquisition. Cambridge: Cambridge University Press.114-138.

ELLIS, R. 2001. Introduction: Investigating form-focused instruction. In Ellis, R (Ed), Formfocused instruction and second language learning. Oxford: Blackwell Publishers.1-46.

FOTOS, SS. 1993. Consciousness raising and noticing through focus on form: Grammar task performance versus formal instruction. Applied Linguistics, 14(4):385-407.

GARCÍA MAYO, M. 2000. English for Specific Purposes: Discourse analysis and course design. Euskai Herriko: Unibertsitata.

GASS, SM. 1995. Learning and teaching: The necessary intersection. In Eckman, FR, D Highland, PW Lee, J Mileham \& R Rutkowski Weber (Eds), Second language acquisition: Theory and pedagogy, Mahwah: Lawrence Erlbaum Associates, Publishers.3-20.

GRENFELL, M. 2000. Learning and teaching strategies. In Green, S (Ed), New perspectives on teaching and learning modern languages. Clevedon: Multilingual Matters Ltd. 123.

HENRY, A \& RL ROSEBERRY. 1998. An evaluation of a genre-based approach to the teaching of EAP/ESP writing. TESOL Quarterly 32(1):147-157.

JORDENS, P. 1996. Input and instruction in second language acquisition. In Jordens, P \& J Lalleman (Eds), Investigating second language acquisition. Berlin: Mouton de Gruyter.407-450.

KUMARAVADIVELU, B. 1993. The name of the task and the task of naming: Methodological aspects of task-based pedagogy. In Crooks, G \& SM Gass (Eds), Tasks in pedagogical context: Integrating theory and practice. Adelaide: Multilingual Matters Ltd.69-76.

LARSEN-FREEMAN, D. 1995. On the teaching and learning of grammar: Challenging the myths. In Eckman, FR, D Highland, PW Lee, J Mileham \& R Rutkowski Weber (Eds), Second language acquisition: Theory and pedagogy. Mahwah: Lawrence Erlbaum Associates Publishers.131-150.

LARSEN-FREEMAN, D \& M LONG. 1991. An introduction to second language acquisition research. London: Longman.

LEOW, RP. 2001. Attention, awareness and foreign language behavior. In Ellis, R (Ed), Form-focused instruction and second language learning. Oxford: Blackwell Publishers.113-155.

LONG, MH. 1985. Input and second language acquisition theory. In Gass, S \& C Madden (Eds), Input in second language acquisition. London: Newbury House Publishers.377393. 
LONG, MH. 2000. Focus on form in task-based language teaching. In Lambert, RD \& E Shohamy (Eds), Language policy and pedagogy: Essays in honor of A Ronald Walton. Philadelphia: John Benjamins Publishing Company.179-192.

LONG, MH \& G CROOKES. 1993. Units of analysis in syllabus design: The case for task. In Crooks G \& SM Gass (Eds), Tasks in pedagogical context: Integrating theory and practice. Adelaide: Multilingual Matters Ltd.9-54.

LONG, MH \& P ROBINSON. 1998. Focus on form: Theory, research and practice. In Doughty, C \& J Williams (Eds), Focus on form in classroom second language acquisition. Cambirdge: Cambridge University Press.15-63.

LOSCHKY, L \& R BLEY-VROMAN. 1993. Grammar and task-based methodology. In Crooks, G \& SM Gass (Eds), Task and language learning: Integrating theory and practice. Adelaide: Multilingual Matters Ltd.123-167.

MCDONOUGH, J \& C SHAW. 2003. Materials and methods in ELT: A teacher's guide. Second edition. London: Blackwell Publishing Company.

MURPHY, DF. 1993. Evaluating language learning tasks in the classroom. In Crooks, G \& SM Gass (Eds), Tasks in pedagogical context: Integrating theory and practice. Adelaide: Multilingual Matters Ltd.139-161.

NUNAN, D. 1993. Task-based syllabus design: Selecting, grading and sequencing tasks. In Crooks, G \& SM Gass (Eds), Tasks in pedagogical context: Integrating theory and practice. Adelaide: Multilingual Matters Ltd.55-68.

ODLIN, T. 1994. Introduction. In Odlin, T (Ed), Perspectives on pedagogical grammar. Cambridge: Cambridge University Press.1-22.

OVERSTRAND MUNICIPALITY. 2001. Unpublished report of interim assistant manager on interpretation and translation services.

OVERSTRAND MUNICIPALITY. 2001. Communication policy and strategy: Overstrand municipality, Hermanus.

PICA, T \& C DOUGHTY. 1985. Input and interaction in the communicative classroom: A comparison of teacher-fronted and group activities. In Gass, S \& C Madden (Eds), Input in second language acquisition. London: Newbury House Publishers.115-136.

PICA, T, R KANAGY \& J FALODUN. 1993. Choosing and using communication tasks for second language instruction. In Crooks, G \& SM Gass (Eds), Task and language learning: Integrating theory and practice. Adelaide: Multilingual Matters Ltd.9-34.

PIENEMANN, M. 1998. Language processing and second language development: Processability theory. Amsterdam: John Benjamins Publishing Company. 
RUTHERFORD, W. 1988. Aspects of pedagogical grammar. In Rutherford, W \& $\mathrm{M}$ Sharwood Smith (Eds), Grammar and second language teaching: A book of readings. London: Newbury House Publishers.171-185.

SAMUDA, V \& PL ROUNDS. 1993. Critical episodes: Reference points for analyzing a task in action. In Crooks, G \& SM Gass (Eds), Tasks in pedagogical context: Integrating theory and practice. Adelaide: Multilingual Matters LTD.125-138.

SEIDLHOFER, B \& HG WIDDOWSON. 1998. Applied linguistics, pragmatics, and language pedagogy. In De Beaugrande, R, M Frosman, B Seidlhofer \& HG Widdowson (Eds), Language policy and language education in emerging nations. London: Ablex Publishing Corporation.3-14.

SHARWOOD SMITH, M. 1993. Input enhancement in instructed SLA: Theoretical bases. Studies in Second Language Acquisition, 15:165-179.

SKEHAN, P. 1996. A framework for the implementation of task-based instruction. Applied Linguistics, 17(1):38-62.

THOROGOOD, J. 2000. Vocational languages: An analysis of current practice and suggestions for a way forward. In Green, $\mathrm{S}(\mathrm{Ed})$, New perspectives on teaching and learning modern languages. Clevedon: Multilingual Matters Ltd.138-157.

VALDMAN, A. 1989. The elaboration of pedagogical norms for second language learners in a conflicting diglossia situation. In Gass, S, C Madden, D Preston \& L Selinker (Eds), Variation in second language acquisition, Volume I: Discourse and pragmatics. Clevedon: Multilingual Matters.15-36.

VAN HUYSTEEN \& B NEETHLING. 2001. Teaching Xhosa for specific purposes to physiotherapy students. Per Linguam, 17(2):12-22.

VAN PATTEN 1996. Input processing and grammar instruction: Theory and research. Norwood: Alex Publishing Corporation.

VAN PATTEN, B. 2002. Communicative classrooms, processing instruction, and pedagogical norms. In Gass, S, K Bardovi-Harlig, SS Magnan \& J Walz (Eds), Pedagogical norms for second and foreign language learning and teaching: Studies in Honour of Albert Valdman. Amsterdam: John Benjamins Publishing Company.105-118.

WIEDEN, W. 1998. How can we teach a foreign language for specific purposes? In De Beaugrande, R M Grosman \& B Seidhofer. Language policy and language education in emerging nations: Focus on Slovenia and Croatia and with contributions from Britain, Austria, Spain and Italy. London: Ablex Publishing Corporation.207-218.

WILLIAMS, J \& EVANS, J. 1998. What kind of focus on which forms? In Doughty, C \& J Williams (Eds), Focus on form in classroom second language acquisition. Cambridge: Cambridge University Press.139-155. 
YULE, G. 1997. Referential communication tasks. Mahwah: Lawrence Erlbaum Associates, Publishers.

\section{Biographic Note}

Mariana Visser is an Associate Professor and Chair of the Department of African Languages. Her main interest is in syntax, second language acquisition and genre studies.

Her current research in the field of second language acquisition and learning relates to formmeaning connections and processing instruction as these issues apply to the learning of African languages by first language speakers of English and Afrikaans, assuming the Task-based approaches. She is also involved in the design of a computer-assisted language learning (CALL) course for isiXhosa for Health Sciences students and staff.

email:mwv@sun.ac.za

Edith Venter has recently completed an MA degree. 